\title{
Rik mans frilla eller fattig mans fru?
}

\section{Frillan och politiken i det medeltida Island}

Af Auður MagnúsdótTir

Äktenskap var under medeltiden ett viktigt politiskt redskap. Det användes för att bilda allianser, stärka vänskapsband mellan familjer och även för att bekräfta försoningar. Kärleken spelade dürför en obetydlig roll när äktenskap planerades. Emellevtid bade mainga böpdingar, gifta som ogifta, frillor. Baserades dessa förbaillanden på ren kärlek eller var det politiken som styrde $i$ dessa fall ocksai?

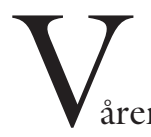

åren 1223 reste

den unge hövdingen Sturla Sighvatsson till Hruni, ett storgods i södra Island. I hans följe var bland andra hans far, Sighvatur Sturluson och hans mor Halldóra Tumadóttir. Herren i huset var Porvaldur Gissurarson, men det var egentligen inte honom Sturla ville träffa. Till porvaldur hade nämligen också rest Solveig Sæmundardóttir, dotter till den förnäme, men nyligen avlidne Sæmundur Jónsson i Oddi, och hennes mor Valgerður, som hade varit Sæmundurs frilla. Sturlas syfte med resan var uppenbart. Solveig var en eftersökt gemål och kanske föll hon pladask för Sturla, som enligt källorna var närmast gudalik i utseende, viljestark och ambitiös och därför ett potentiellt storhövdingämne. Man kom överens om villkor för äktenskap mellan de två, bröllopet hölls omedelbart i Hruni och Solveig reste hem til Sauðafell tillsammans med Sturla. Innan de anlände hade dock Sturlas mor, Halldóra, sett till att Vigdís Gíslsdóttir 
skickades därifrån. Hon anordnade en följesman och bad honom helt enkelt ta hem Vigdís till sin far. Íslendingasagas författare, Sturla Pórðarson, förklarar för läsaren att Vigdís hade varit Sturlas frilla sedan en tid tillbaka och att tillsammans hade de dottern Puríður (Stu I, 300). Vid denna tid var det inte längre vanligt att män hade både hustru och frilla under samma tak, även om ärkebiskopen i Nidaros hade anklagat hövdingar på Island för sådant leverne runt 40 år tidigare (DI, I 218-223 och 260-264). Möjligheten finns att Sturla behöll sin frilla och i fortsättningen besökte henne hos hennes far i Miðfjörður, men sådana antaganden kommer endast att förbli gissningar. Däremot höll Sturla kontakten med Vigdís far och hennes bröder. De var vänner och allierade och att Sturla gifte sig och kanske till och med bröt kontakten med Vigdís verkar inte ha ändrat den situationen.

Sturla är en färgstark gestalt i fristatstidens historia och en av de viktigaste politiska profilerna. Om honom har vi riklig information och genom hans politiska aktivitet får vi dessutom veta litet mer om Gísl och hans söner. Vigdís är däremot borta ur handlingen i och med Sturlas äktenskap. Bara en gång till i det stora samlingsverket Sturlunga saga făr vi en glimt av denna kvinna; en glimt som blir aktuell senare i denna artikel.

Vigdís är bara en av många frillor som förekommer i Sturlunga saga. Det är uppenbart att frillolevnad var vanlig på Island, både bland hövdingar och i de lägre sociala klasserna. Här fanns det dock en viktig skillnad, hövdingar hade ofta många frillor medan frilloförhållanden bland de lägre sociala skikten oftast var monogama. Det var uppenbarligen enkelt att bryta ett frilloförhållande och skicka iväg frillan; som Sturla Sighvatsson gjorde när han gifte sig. Hur kvinnorna upplevde denna situation får vi naturligtvis inte reda på; det är emellertid tydligt att frillorollen inte var skamlig och kvinnorna och deras förmyndare måste egentligen varit väl medvetna om hur förhållandet kunde sluta. Med tanke på hur stor vikt som lades vid att värna om kvinnans heder, hur stränga straff lagboken Grágás utmäter för sexuella övergrepp är det därför uppseendeväckande att hövdingar kunde ta döttrar till välbärgade storbönder som frillor och när de tröttnat på kvinnorna skicka dem tillbaka till deras familjer. Förklaringen måste ligga i frilloväsendets sociala roll, d.v.s. att både mannen som tog frillan och frillans förmyndare fick något ut av förhållandet. Kontraktet som antagligen gjordes när ett frilloförhållande inleddes måste alltså ha inneburit ömsesidiga plikter, men också någon vinst för bägge parter. Äktenskapets roll i medeltidens politik är numera allmängods. I det följande är det meningen att se på frilloväsendets roll i det politiska livet på Island under fristatstiden. Koncentrationen ligger på perioden 1150 till 1264, den tid vi har rikligast källmaterial om (Jfr Magnúsdóttir, 1996, Sigurðsson 1993, 12-38, Byock $1990,14-30)$. Syftet är att se på hur frilloväsendet som institution användes i den politiska maktkampen. Detta perspektiv utelämnar emellertid oftast kvinnorna själva, eftersom de sällan var politiskt aktiva. Deras sociala ställning är dock inte mindre viktig och man kan självklart inte utforska frilloväsendet utan att se närmare på själva förutsättningen för frillolevnaden, nämligen frillorna. Vilken var deras roll i ett frilloförhållande, vilka möjligheter hade de att påverka sin egen ställning och sina barns uppfostran? Kunde hövdingens frilla utnyttja sin ställning för att påverka den politiska maktkampen som utspelade sig i fristatstidens slutskede?

Innan vi ger oss i kast med dessa frågor är det emellertid nödvändigt att se på den forskning som gjorts runt frilloväsendet i Europa och dess relevans för isländska förhållanden. 


\section{EN INTERNATIONELL FÖRETEELSE?}

Till följd av nya riktningar inom historievetenskapen har ett ökad intresse på senare tid riktats mot kvinnornas situation i historien. Blickarna har därför naturligt fallit på deras roll som mödrar, hustrur och älskarinnor. Äktenskapet var förutom klosterliv en av två "karriärmöjligheter" under medeltiden. Förutom att se på kvinnornas liv inom äktenskapets ramar samt naturligtvis även deras möjligheter att påverka val av make, har kristendomens inflytande på äktenskapet studerats. I samband med detta har det varit oundvikligt att ta hänsyn även till frilloväsendet; den samlevnadsform som fördömdes och bekämpades av kyrkan (Se t.ex. Stafford, 1983, Wemple, 1981, Goody 1976, 1983).

Mest vikt har i forskningen lagts på att definiera frillorollen som sådan samt klarlägga illegitima barns rättigheter, huvudsakligen vad gäller arv. Även om frilloförhållanden var långvariga och $\mathrm{i}$ de flesta fall resulterade i ett antal illegitima barn ger de medeltida lagarna allmänt inte någon information om hur sådana förhållanden ingicks. Därför har frillan ingen definierad status enligt lagen som Margaret CluniesRoss påpekar i sin artikel om frilloväsendet hos anglosaxerna. Skillnaden mellan en hustru och en frilla var enligt henne först och främst den att frillan köptes inte med mund (dowry) som hustrun, men att frillan trots detta hade vissa rättigheter och att hennes barn kunde ärva om mannen erkände faderskapet. (Clunies-Ross, 1985, 6) Frillans ställning behövde därför inte vara skamlig. Det faktum att de inte nämns i lagarna hade inte heller som självklar följd att de var utan rättigheter. I sin artikel visar Clunies-Ross att frillorna under den tidiga kristna perioden var en del i mannens hushåll och att deras barn kunde ärva. Det var dessa rättigheter den anglo-saxiska kyrkan bekämpade (Clunies-Ross, 1985, 4).

Frillolevnad och/eller polygami var en vanlig företeelse bland frankerna och saxerna, men kanske mest långlivat bland ir- ländarna. Där var det "världsliga äktenskapet" norm fram till runt sekelskiftet 1600 . Det betydde att skilsmässa var tillåten och att de i övre klasserna kunde gifta om sig. Det gällde både för kvinnor och män $(\mathrm{Ni}$ cholls, 73).

I Skandinavien mötte den kristna äktenskapspolitiken samma motstånd som $\mathrm{i}$ andra europeiska länder, om inte hårdare. Den fornnordiske litteraturen ger en inblick i äktenskapet och andra samlevnadsformer som praktiserades under tiden fram till ca 1300 i Norge och på Island. Vid närmare granskning reflekterar detta källmaterial den konflikt som uppstod mellan kyrkans syn på äktenskap och samliv och inhemska traditioner. Den danske historikern Thyra Nors har tecknat en bild av kyrkans försök att föra ut sin syn på äktenskapet i Danmark (Nors, 1987, 28-45). Hon påpekar att meningskiljaktigheterna mellan geistliga och världsliga nådde sin kulmen omkring 1200 . Därför är hennes syfte att granska samtida källmaterial för att igenom kritiska studier av detta kasta ett nytt ljus på hur konflikterna utspelade sig i Danmark. Hon anser bl.a. att landskapslagarnas tystnad om frillor (slegfred) inte utesluter att de hade "sxdvanebestemte rettigheder" och att det finns inget där som bekräftar att hon hade en "lav, besiddelsesløs status." Detta tillstyrks av den vikt som läggs på frillobarnens arvsrätt i landskapslagarna. Nors resultat är därför jämförbara med Clunies-Ross. Nors hävdar vidare att om man läser lagarna med kritiska ögon framstår frilloinstitutionen som ett fullt legalt forhållande som ingicks efter överenskommelse med kvinnans släkt, på samma sätt som äktenskap. Det är på grund av detta som det i lagarna åläggs särskilda straff för att ingå ett illegalt förhållande utan släktens samtycke (Nors, 1987, 39).

Nors understryker vikten av att läsa landskapslagarna som kompromisser på konflikter som utspelade sig mellan lagarnas upphovsmän. Hon tar som ett exempel den bestämmelse som behandlar hävdäktenskap 


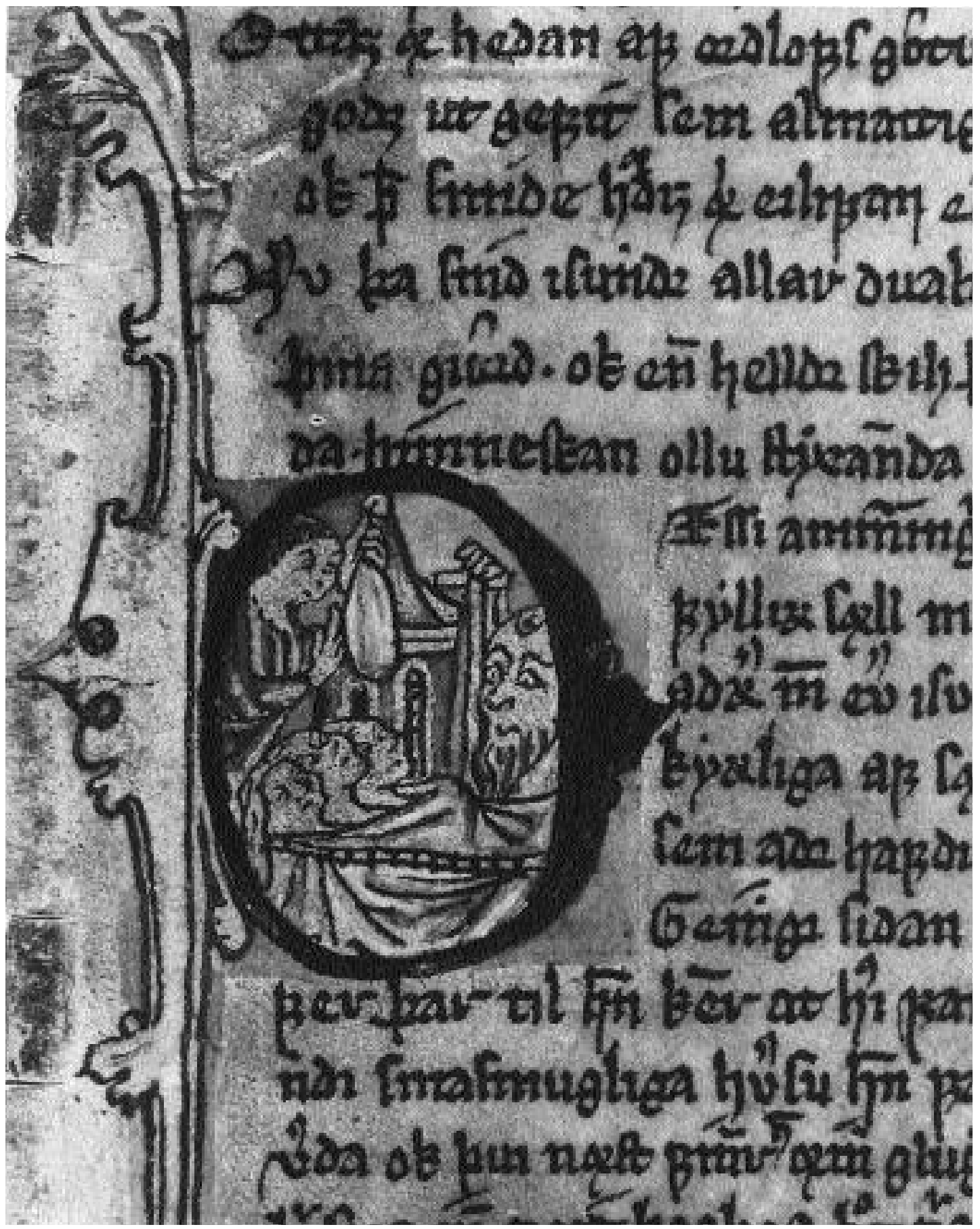

St. Nikolaus, frain Helgustaðbók, Stk. perg. 4 to nr. 16, bl. 12k. Här efter Íslensk Miðaldahandrit II, 1982, mynðblat (bild) 27. Manuskriptet frain slutet av 1300-tallet.

Bilden visar St. Nikolaus när han räddar tre systrar frain att bli frillor. Sagan berätter att en bonde hade gjort sig av med alla pengar och kunde därför inte gifta bort sina döttrar. Nikolaus kom til undsätning - han gav bonden en paise full med guld - varvid döttrarna kunde giftas bort och behailla äran. Allt efter kyrkans föreskrifter. 
och där den säger att en man högst kan ha en kvinna hos sig $\mathrm{i}$ tre år, men att hon därefter betraktas som en äkta hustru. Istället för att tolka denna bestämmelse som tidigare forskning har gjort, dvs att detta ger uttryck för sedvana, menar Nors att bestämmelsen i sig är ett tecken på kompromiss. Det konfliktfyllda visar sig enligt henne i behovet av att nedteckna bestämmelsen skriftligt (Nors, 1987, 35).

Thyra Nors lägger i sin artikel ganska stor vikt vid kyrkans inflytande på sexualiteten. Detsamma gör Jenny Jochens som i ett antal artiklar har studerat äktenskap och kärleksliv utifrån den fornnordiska litteraturen, huvudsakligen kungasagor och islänningasagor och till en viss del samtidssagorna.(Se Jochens, 1980, 1982, 1985a, 1985b, 1987, 1992, 1995)

Islänningasagorna och samtidssagorna visar två olika bilder av äktenskap och samlevnadsformer. I de förstnämnda respekteras det monogama äktenskapet med få undantag (Jochens, 1980, 379) men kontrasterna till denna bild finner man i Sturlunga saga. Där är äktenskapet inget hinder för att män även kan ha frillor, ofta många. Även de illegitima barn som blev följderna av dessa förhållanden nämns och spelar ofta en viktig roll i handlingen. Jenny Jochens trycker på att kyrkans regler angående sexualiteten inte var respekterade under 1200-talet, vilket man även kan se av att kyrkans män inte levde i celibat. Kontrasterna mellan islänningasagor och samtidssagor blir ännu mer slående med tanke på att de till stor del har samma tillkomsttid. Den monogama bild som visas $i$ islänningasagorna kan enligt Jochens tyda på konflikten mellan det kristna idealet och inhemsk tradition (Jochens, 1980, 389).

I sin artikel "The Politics of Reproduction" tar Jochens upp de norska kungarnas utomäktenskapliga förhållanden (Jochens, 1987, 327-349). Hon behandlar tiden mellan Harald hårfager och Håkan den gamle (ca 870-1260) och påpekar att det under denna period fanns vissa fördelar för en kvinna, liksom hennes släkt, att ha ett förhållande med en man av högre social börd, i det fall hon tar upp, kungar. Eftersom alla söner, legitima liksom illegitima, kunde kräva kungadömet kunde en sådan relation föra familjen upp ett eller flera trappsteg i den sociala hierarkin. Även om paret inte fick barn ihop kunde släkten hoppas på någon värdighet på grund av sitt inofficiella släktförhållande med kungen. För kungen själv kunde detta betyda trogna anhängare, allierade med andra ord (Jochens, 1987, 536).

På Island kom kampen för det monogama äktenskapet i gång i slutet av 1100talet när Porlákur Pórhallsson blev biskop. Oftast betraktas två brev från ärkebiskop Eystein Erlendsson i Nidaros till isländska hövdingar, som upphovet till kyrkans kamp för moralisk upprustning (DI, I 218-223, 260-264). Eysteins utsände på Island, biskop Porlákur, förde dock sin kamp i stark motvind och hans budskap hade föga effekt i praktiken. Emellertid ser det ut som om hövdingar i slutet av 1100-talet och på 1200-talet i större utsträckning väljer mellan ett äkenskap och ett frilloförhållande. Äktenskap var enligt kyrkan ett heligt band, ett sakrament. Att besudla ett sådant medförde hot om bannlysning. De ogifta som levde i ett, eller flera, frilloförhållanden hade inte åtagit sig några löften. Deras förhållande var inte välsignat och de gjorde sig därför i teorin inte skyldiga till ett lika stort brott som de gifta som hade utomäktenskapliga kärleksförhållanden, och därmed gjorde sig skyldiga till hordom.

Kyrkans idéer om det heliga äktenskapet hade varit kända på Island långt innan Porlákur blev biskop. Hövdingarna visade dock kraftit motstånd mot hans strävan. Orsakerna var fler än här ges utrymme för att nämna. En av de viktigaste kan dock ha varit den politiska instabilitet som präglade den isländska fristatens slutskede. 
ÄKTENSKAPET SOM POLITISKT VERKTYG

Under 11- och 1200-talen undergick det isländska samhället dramatiska förändringar. Karaktäristiskt för perioden är maktkoncentrationen, d.v.s. ändringen från att vara ett samhälle som var kontrollerad av många, och åtminstone teoretiskt, lika mäktiga godar, till det som man ser i början av 1200-talet när fem släkter brottades om makten. Den senare delen av fristatstiden präglades av maktfejder som pågick enda fram till dess undergång år 1262/64. I moderna ordalag skulle man helt enkelt kunna beskriva perioden som en tid av inbördeskrig, präglad av konstanta strider mellan och även inom - familjerna. Under samma tid växte en ny klass fram, nämligen storbönderna. Detta var rika bönder och många av dem hade stort inflytande inom sina egna härader. Godarna hade blivit färre, hade kontroll över större områden än tidigare, men samtidigt inte kapacitet att kontrollera så stora geografiska områden som många av dem nu besatt. Samtidigt blev de allt mer beroende av ett alliansnät och viktiga delar av det blev nu storbönderna. Hade godarna storböndernas förtroende kunde det betyda att även storbondens vänner blev allierade med de förstnämnda.

Här finns inte utrymme för att gå närmare in på denna utveckling. Det är dock nödvändigt att understryka att under den tid som är relevant här blev det allt viktigare att vara allierad med rika och mäktiga hövdingar och bönder. Hövdingarna var beroende av att ha trogna följesmän. Äktenskap var ett effektivt verktyg i denna strävan på Island som annorstädes i Europa. Det var vanligt att man stiftade äktenskap för att skapa ett band mellan två familjer, men det användes även för att bekräfta försoningar eller för att bekräfta vänskap. Hövdingar, så som Snorri Sturluson och hans bror pórður, både stärkte och ökade sin makt genom äktenskap. Pórður gifte sig först med Helga Aradóttir men de skilde sig snart eftersom "han inte kunde älska henne som han skulle" (Stu I, 231). Några år sen- are gifte han om sig med änkan Guðrún Bjarnadóttir. Detta äktenskap hade stor betydelse för Pórður, om inte känslomässigt, så ekonomiskt. En liten kommentar i Íslendinga saga bekräftar vikten av detta förhållande; "Med henne fick han stora egendomar. Då blev pórður hövding." (Stu I, 232).

När Snorri Sturluson var giftasvuxen hade hans mor gjort slut på det arv han hade fătt efter sin far, Sturla Pórðarson. Snorri var därför i förhållande till sin sociala ställning, ganska fattig. Hans bror Pórður och fosterbrodern Sæmundur Jónsson i Oddi friade för Snorris räkning till Herdís Bersadóttir, dotter till Bersi den rike, vars fru emellertid hade varit pórðurs älskarinna. Bersi var, som namnet intygar, rik men inte av lika hög social ställning som Snorri. Snorri kunde på detta sätt förbättra sin ekonomiska situation genom äktenskap. Tillsammans med Herdís fick han två barn, men äktenskapet blev som väntat inte lyckligt. Snorri hade några frillor och fick tillsammans med dem tre barn som vi vet om. Sina tre döttrar använde han senare för att öka och stärka sin egen politiska ställning genom att gifta bort dem till lämpliga politiska allierade.

Äktenskap var ett viktigt politiskt verktyg. För att kunna ingå lagligt äktenskap ställdes emellertid många krav. Ett var förmögenhet, d.v.s. det blivande paret skulle kunna visa att de kunde försörja sig själva, ett problem som knappast rörde de övre sociala skikten. Ett annat krav var social och ekonomisk jämbördighet och ett tredje var kravet om att parterna skulle vara obesläktade. Under denna aktuella period var islänningarna inte fler än 40-60000 och endast en bråkdel av dessa tillhörde de övre sociala klasserna. Det säger sig därför självt att det kunde uppstå problem när barnen skulle giftas bort och alliansnätverk skapas. För många av dessa kunde därför frilloväsendet fungera som ett alternativ, om inte annat, $\mathrm{i}$ väntan på något bättre. Sturla Sighvatsson var en av många som ville ha Solveig 
Sæmundardóttir till hustru. När han nu fick denna lyckliga lott var det värt att skicka iväg Vigdís och åtminstone försöka att hålla löftet om monogami.

\section{FRILLOLEVNAD - \\ MAKTMEDEL ELLER LUSTA?}

Som tidigare nämnts var ett frilloförhållande ett långvarigt förhållande, som i de flesta fall ingicks efter förhandlingar med kvinnans förmyndare vid äktenskap. Det skiljer sig därför ifrån korta kärlekshistorier, som såväl "en natts äventyr" som andra tillfälliga relationer. Frilloförhållanden praktiserades både bland hövdingar och i de lägre sociala klasserna. Hövdingen hade emellertid ofta flera frillor medan frillolevnad bland de mindre privilegerade oftast var monogam. Trots att kvinnorna oftast var av lägre social börd än mannen, kunde de ändå vara av relativt hög börd. Således var Guðrún, Snorri Sturlusons frilla, illegitim dotter till Hreinn Hermundsson. Hennes farfar var därför gode, liksom hennes styv-far. Ett annat exempel är Sæmundur Jónssons frilla Valgerður á Keldum, som var Sæmundurs kusin.

Frillorna bodde inte nödvändigtvis ihop med sina män. Jón Loftsson i Oddi hade visserligen sin frilla, Ragnheiður pórhallsdóttir hemma på gården, tillsammans med hustrun, (Bisk I, 282) men frågan är om inte det hade blivit sällsynt att gifta män höll sina frillor hemma i slutet av 1100-talet. Enligt Sturlunga saga var det vanligt att frillorna bodde så eller drev gårdar som sannolikt var i mannens ägo. (Se t.ex. Stu I, 242). Frillorna hade i dessa fall troligtvis samma roll som en hustru. Frillorna var emellertid ingen homogen grupp. De kom från olika sociala klasser och deras situation kunde bero lika mycket på deras egna sociala bakgrund som på mannens. Vidare fanns det naturligtvis olika skäl till att folk valde att leva i ett frilloförhållande. Kanske kunde även de bakomliggande orsakerna bestämma frillans situation.
För klarhetens skull har jag på grund av frillornas olika roll och status som den framkommer i samtida material delat upp frilloförhållandena i fyra grupper. Uppdelningen används först och främst som ett verktyg och bör ses som ett sådant. Grupperna kan grovt definieras på följande sätt.

Först förhållanden mellan dem som inte hade råd att gifta sig. Som vi har sett krävdes ett visst minimum av egendom för att kunna ingå ett äktenskap. De som inte kunde visa upp denna summa levde dock sannolikt inte alla i celibat. Det finns i Sturlunga saga både exempel på arbetsfolk och småbönder som levde i frilloförhållanden. Således bodde Sigmundur snagi, hövdingen Sturla Sighvatssons följesman, på gården Eyðihús i Fáskrúðsfjörður tillsammans med sin frilla Helga och deras gemensama barn (Stu I, 308). Andra bodde på var sin gård med goda kontakter (Stu I, 218).

Vi kan inte heller bortse från att frilloförhållanden kunde grunda sig på kärlek. Äktenskapet var emellertid släktens angelägenhet snarare än individernas och kärleken inte samma självklara förutsättning för äktenskap som den är idag. Vidare kunde krav om jämbördighet och släktskap stå i vägen för förälskade par som funderade på att gifta sig i det medeltida samhället. Ett alternativ var då att leva i ett illegitimt förhållande, vilket Jón Loftsson sägs ha gjort med sin älskade Ragnheiður. De skall enligt sagan ha älskat varandra sedan de var barn. Detta ett ganska vidlyftigt leverne till trots. Författaren påpekar ärligt att Ragnheiður hade barn med andra män än Jón och att han i sin tur "...var mycket för kvinnors kärlek och därför fick han söner med många andra kvinnor än sin hustru." (Bysk, 25l) Bland dessa var alltså Ragnheiður. De fick två söner ihop, Ormur och Páll.

Tredje gruppen är de hövdingar som inte träffade någon jämbördig, obesläktad att gifta sig med och därför i brist på annat valde frillor istället. I denna grupp är Jón Loftssons legitime son, Sæmundur, den för- 
nämste av de fall som finns i Sturlunga saga. Jón Loftsson var enligt sägnen ättling till kung Magnus barfot. Kanske var det på grund av denna ädla påbrå som Sæmundur hade svårt att hitta en jämbördig kvinna bland Islands alla bonddöttrar. Författaren understyrker problemet med att påpeka att jarlen på Orkneyöarna och Sæmundur hade förhandlat om giftermål mellan jarlens dotter, Langlíf, och Sæmundur, men att jarlen inte ville skicka kvinnan till Island och Sæmundur inte ville ha sitt bröllop på Orkneyöarna (Stu I, 242). Hade Sæmundur gift sig med Langlíf hade han sannolikt varit tvungen att skicka iväg alla sina frillor. Sturlunga saga nämner sammanlagt fyra och tillsammans med dem fick han 11 barn. Det är inte osannolikt att han även hade fler förhållanden än dem som nämns.

Sæmundur befinner sig dock på gränsen till den fjärde gruppen, den jag har valt att nämna "politiska frilloförhållanden." Jag menar att man i många fall valde sina frillor strategiskt på samma sätt som man planerade äktenskap. Det är här det politiska läget på Island under fristatstiden blir särdeles aktuellt. Allteftersom maktkampen hårdnade blev det viktigare med alliansbildande. Något förenklat kan man säga att genom äktenskap kunde man skapa allians endast med en släkt. Genom frilloförhållanden kunde man skapa flera allianser. Kan inte förklaringen vara just alliansbildande, behov av lojalitet och tillgång till många anhängare, tingmän? Genom att bilda kontakter med storbönderna, som ofta var ledare för andra bönder i sina respektive områden, stärkte hövdingarna sin ställning där de kände sig svaga.

Många bönder valde frillorollen framför äktenskap för sina döttras del, vilket tyder på att även de drog fördelar av frilloförhållandena. Det troligaste är att de fick viktiga kontakter och att det öppnades en möjlighet att komma upp sig i samhället. Flera exempel på detta finns inom släkten Sturlungar:
Vi kan först återigen se på Sturla Sighvatssons förhållande med sin frilla Vigdís. Trots att Sturla ingick äktenskap med Solveig Sæmundardóttir förblev frillans familj och Sturla allierade. Frillans far var Gísl Bergsson, bonde i Miðfjörður. Han och hans fem söner följde Sturla och hans far, Sighvatur. Det gjorde också Gísls bror, Dorbjörn och hans son. Men inte nog med det. Porbjörns dotter var i sin tur gift med Ásgrímur Bergpórsson, en framstående bonde. Också han blev Sturlas och Sighvaturs följeslagare.

Alla dessa kontakter bildades till följd av Sturlas frilloförhållande, och bröts inte trots att förhållandet tog slut och frillan giftes bort. Sturla och Sighvatur fick trogna följeslagare där de behövde dem, och för bönderna betydde det ett socialt steg uppåt, skydd och allians med en mäktig släkt. Det tycks tydligen ha givit bra resultat; Vigdís Gíslsdóttir systerdotter blev sedan frilla till en annan mäktig hövding, Bjarni Sæmundsson av Oddaverjasläkten.

Både Sighvatur och Sturla dödades i slaget vid Örlygsstaðir, och deras makt föll i andras händer. Då Sturlas bror, Pórður kakali, kom hem från Norge 1242 ville han både ha hämnd och de enligt honom rättmätiga egendomarna tillbaka. För att uppnå den maktställning han var ute efter fick han ta till alla medel. pórðurs nätverk med allianser och belöningar till trogna är som det framställs i Sturlunga saga ett intressant fenomen.

pórður fick enligt Sturlunga saga fem barn ihop med fyra kvinnor (Stu II, 85). En av dem var frillan Kolfinna porsteinsdóttir, vars far var Porsteinn Jónsson, “den bäste bonden" i Vatnsdalur på nordlandet. Både han och hans son Eyjólfur ofsi, hade deltagit på Sturlas och Sighvaturs sida i slaget vid Örlygsstaðir. Nu knöt Pórður kontakter med dem igen. Han gjorde sitt för att åstadkomma ett äktenskap mellan Eyjólfur ofsi och puríður, Sturla Sighvatssons illegitima dotter; den dotter han hade fått ihop med Vigdís (Stu II, 81). Eyjólfurs syster, den tigidare nämnda Kolfinna, blev däre- 


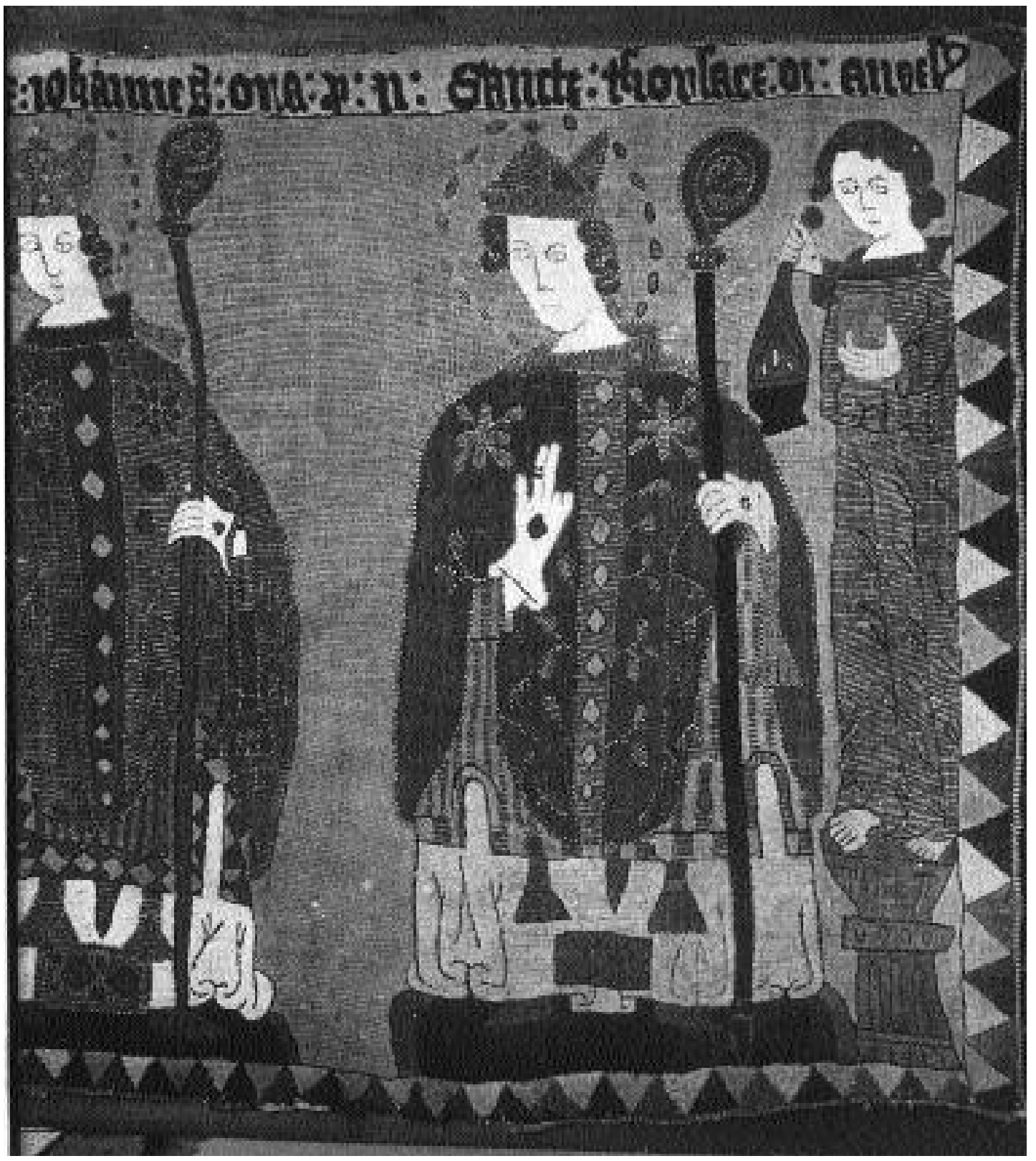

Porlákur Pórhallsson den heliga. Del av altarklädsel fràn domkyrkan på Hólar i Hjaltadal. Frain förra delen av 1500-talet. Nationalmuseet på Island. Foto: Gisli Gesteson. 
mot pórðurs frilla. Hon drev gården Geldingaholt. En annan trogen anhängare till pórður kakalis familj var Hrafn Oddsson, och han blev gift med puríður, Sturla Sighvatssons legitima dotter. Det kommenteras i sagan med att Hrafn friade till puríður, och att Pórður gav honom allt sitt stöd (Stu II, 70). Eyjólfurs och Hrafns belöning var inte endast de fördelaktiga äktenskapen; de blev båda inflytelserika hövdingar, och när pórður kakali åkte till Norge var de bland dem han gav fullmakt för sitt område (Stu II, 118-119).

porgils skarði, pórður kakalis brorson, återkom till Island 1252. Han hade en frilla och gifte sig inte. Hans "svärfar" var Gunnar Klængsson, "göfugur bóndi” (ädel bonde) på nordlandet. Båda Gunnars döttrar blev frillor, den ena till Gissur Porvaldsson, som sedan blev jarl över Island och den andra till porgils skarði (Stu I500-501, II, 209). Både Gissur och Porgils var mäktiga hövdingar och sannolikt mycket viktigare allianser än bonden Gunnar Klængsson kunde ha fătt genom att gifta bort sina döttrar till sina jämlika. För familjen bidrog kontakterna med dessa hövdingar sannolikt till böndernas högre status. Illugi Gunnarsson, kvinnornas bror, representerade sitt område när nordlänningarna accepterade att betala skatt till Norge 1262 (Stu II, 181). Genom sina förhållanden fick Porgils trogna anhängare på nordlandet, där han försökte stärka sin ställning, och Gissur nödvändiga kontakter som den norske kungens sändebud.

Här har jag endast nämnt exempel från släkten Sturlungar, men paralleller finns i andra släkter. Vi kan konstatera att val av frillor i många fall styrdes av strategi, precis som vid valet av hustrur. Frillornas politiska roll kan vara en förklaring till varför hövdingar motsatte sig kyrkans krav på monogami och respekt för det heliga äktenskapet. En annan kan vara att islänningarna hade svårt att anpassa sig både till kravet om de förbjudna leden och äktenskap, samtidigt som praxis var att gifta sig inom de egna sociala skikten. I vilket fall som helst är det tydligt att frilloväsendet spelade en viktig roll i det politiska spelet, inte mindre för frillans familj än för hövdingen själv. Hur viktig var då denna roll för kvinnan själv?

\section{FRILLAN- MOR OCH MAKTHAVARE?}

Som tidigare har påpekats var frilloväsende och/eller polygami vanligt hos Frankerna. Historikern Susan Wemple understryker att frillolevnad praktiserades under hela perioden 500-900, vilken hon också behandlar i sin bok om de frankiska kvinnorna (Wemple, 1981). Som ett exempel på promiskuösiteten tar hon kung Dagobert I som i slutet av 600-talet hade så många frillor att hans historieskrivare underlät att räkna upp dem eftersom boken då hade blivit för stor! (Wemple, 1981, 38-39) Frillorna var ofta arbetskvinnor eller slavar, men Wemple understyker emellertid en påföljd av sexuella förhållanden mellan män av hög social börd med kvinnor av lägre börd, vare sig de var bihustrur eller frillor, som har en viss relevans även här. Detta är den sociala mobilitet polygamin och frilloväsendet erbjöd. Bland Merovingerna var det vanligt att kvinnor av låg social börd kunde gifta sig uppåt i samhället. Frillor kunde hoppas på att förhållandet gjordes legitimt med tiden och därmed uppnå de rättigheter som tillföll en laglig hustru. Detta kunde få oanade konsekvenser; Wemple nämner exempel på fyra drottningar, regerande på 600-talet, som började sina karriärer som slavar (Wemple, 1981, 57)

Även om det ofta kan vara tveksamt att dra paralleller mellan sociala företeelser i så skilda tidsperioder anser jag att det här är berättigat. Trots avstånd $\mathrm{i}$ tid och rum går det att se mönster vad gäller frillolevnad och/eller polygami som fortfarande under 11- och 1200-talen är fullt gällande. Genomgående är till exempel att ett frilloförhållande är en slags undergrupp till ett lagligt äktenskap och att detta stiftades med 
en kvinna som var av lägre social börd än vad mannen var. Förhållandet var informellt så till vida att det inte utväxlades gåvor men fullt offentligt och långvarigt. En annan, och i detta sammanhang viktig, parallell är den sociala mobiliteten frilloväsendet erbjöd. I det isländska samhället kunde frillans familj komma upp sig i samhället till följd av ett sådant förhållande. Hur berörde detta då frillan själv. Åtnjöt hon större respekt som en frilla till en hövding än som en äkta kvinna till en man av samma sociala status som hon var själv? Kunde hon genom sin ställning som frilla t.o.m. påverka det politiska maktspelet?

Bonddöttrar som blev frillor till hövdingar och drev gårdar i deras ägo hade troligen samma makt hemma på gården som legala hustrur. I vissa fall kunde frillorna rent av ärva de gårdar de drev, som Borghildur, Sæmundur Jónssons frilla. Hon ärvde jorden Vellir och "mycket annat" säger Sturlunga saga. (Stu I, 271). Sæmundur tog överhuvudtaget väl hand om sina frillor och illegitima barn. Frillan Valgerður tog hand om gården Keldur, och Yngvildur Eindriðadóttir har sannolikt varit i samma situation, även om vi inte vet vilken gård hon tog hand om. Rent materiellt kan frillorna således haft det bättre än vad de hade haft som äkta hustrur, men förhållandet var givetvis osäkert.

Vad hände med dessa kvinnor om de blev lämnade? Kunde de eventuellt vänta sig ett bättre gifte än innan de blev frillor? Efter påtryckningar från biskopen porlákur pórhallsson tvingades Jón Loftsson slutligen lämna sin älskade Ragnheiður. Oddaverjaflátturs författare visar stort intresse för denna separation - men endst från Jón Loftssons perspektiv. Om Ragnheiðurs känslor och reaktioner făr vi inget veta. Hur hon reagerade, eller om hon gav sitt samtycke till äktenskapet med en viss Arnpór, snart efter separationen förblir därför en gåta (Bisk I, 293). Hennes tidigare frilloförhållande med en hövding medförde troligen inte ett gifte av högre börd.
Vigdís Gísldóttir, Sturla Sighvatssons frilla, nämns endast en gång efter att hennes förhållande tog slut. Detta är hela 15 år efter Sturlas död, då hon sägs vara gift med Ófeigur Eiríksson. Tyvärr vet vi inte när detta äktenskap ingicks och Ófeigurs sociala status nämns inte men något hövdingämne var han inte. En lockande tes är att Sturla höll kontakten med Vigdís även efter giftermålet, att hon bodde kvar hos sin familj där Sturla kunde träffa henne och dottern puríður, och att hon blev bortgift först efter det att Sturla hade blivit dödad. Hennes anknytning till Sturla tycks i allafall ha präglat hennes tillvaro, även långt efter hans bortgång. Gizur porvaldsson, som dödade Sturla, ville inte ha paret inom sitt område och drev därför bort dem. Frågan är om Vigdís och Ófeigur ansågs vara ett hot mot Sturlas gamla fiender och en förolämpning mot Gizurs vänner. Intressant i sammanhanget är emellertid att Vigdís med god hjälp av sin och Sturlas gemensamma dotter, Puríður, lyckas åstadkomma hämnden efter Sturla (Stu I, 481, 484-494). Således påverkar de den politiska utvecklingen indirekt.

Kvinnornas öden och äktenskap går i många fall att kartlägga. Ur källkritisk synpunkt är det däremot svårare att se huruvida de kunde påverka politiken. Surlunga saga är, som isländska sagor i övrigt, starkt mansdominerad och överklasscentrerad. Kvinnors indirekta påverkan i det politiska maktspelet nämns sällan utom då de hetsar till hämnd. Kvinnor deltar heller inte i strider på samma sätt som män och för sällan egen talan. Däremot får vi inte glömma att kvinnor faktiskt kunde ha "makt" över män just på grund av sitt kön. De hade förmågan att driva män till våldshandlingar, kanske mot löften om ett pris bestående av dem själva (Arnórsdóttir, 1996, 124130.).

I Sturlunga saga hittar vi även starka, självständiga kvinnor; kvinnor som påverkar politiken direkt genom sitt handlande. Exempel på detta är kusinerna Steinvör Sig- 
hvatsdóttir, syster till Sturla, och Pórdís Snorradóttir, Snorri Sturlusons dotter. De var emellertid både av hög börd, Steinvör gift och Pórdís änka. Änkor hade en speciell ställning i samhället. De var mer självständiga än gifta kvinnor, de kunde själva ansvara för sin ekonomi och åtminstone några av dem hade älskare. Denna självständighet kan även ha tillfallit de frillor som överlevde sina "män".

Som tidigare nämnts ärvde Borghildur, Sæmundur Jónssons frilla, bland annat jorden Vellir. Hon kunde därför gifta bort sin dotter. Hennes söner ärvde likaså. Valgerður bodde kvar på Keldur och åtnjöt tydligen respekt. När Sturla gav sig ut på friarresa, den som nämndes i början av denna artikel, fanns Valgerður vid sin dotters sida i Hruni. Valgerður var inte sin dotters förmyndare, men antagligen var hon rådgivande när förhandlingar satte igång och kunde därför påverka dem. Det är därför möjligt att "frilloänkor” ofta fick samma status som änkor i övrigt. Huruvida de då blev politiskt aktiva tiger källmaterialet om. Dessa kvinnor verkar vidare ha befunnit sig i en bättre situation än de frillor som blev lämnade av sina “män”. Frillorollen ansågs visserligen inte vara skamlig, att vara frilla till en mäktig hövding kunde tvärtom vara av värde. Den erfarenheten medförde emellertid inte att frillorna senare kunde få ett bättre gifte än innan. Upphöjd status och makt verkar i dessa fall snarare ha tillkommit frillornas fäder, bröder och barn.

\section{SAMMANFATTNING}

Under fristatstidens slutskede blev allianspolitik allt viktigare. För att stärka sin ställning tog hövdingar till alla medel, bland dem äktenskap och frilloförhållanden. Frillan var alltid av lägre social börd än vad mannen var, men hon kunde ändå vara av relativt hög börd. Förhållandet var långvarigt och offentligt och ingicks efter förhandlingar mellan frillans förmyndare och den man hon nu skulle följa. Frillorna drev ofta gårdar i mannens ägo och innehade då en "hustruroll". Detta kan dock ha varit vanligare bland frillor till ogifta män, men sådana förhållanden hade enligt kyrkan annan status än de som gifta män var inblandade i. Frillorollen ansågs inte vara skamlig och kunde medföra högre social status, åtminstone för frillans familj och hennes barn.

På grund av bristande källmaterial går det inte att kartlägga frillornas möjligheter att påverka eller delta $\mathrm{i}$ det offentliga politiska livet. De verkar dock som “änkor” har haft en relativt självständig ställning som enligt min mening går att jämföra med de “riktiga” änkornas självständiga tillvaro.

\section{LITTERATUR}

Arnórsdóttir, Agnes S, "Metode og islandsk middelalder politikk." Rapport III, Fra kvinnehistorie til kjønnshistorie? Det 22. nordiske historikermøte Oslo 13.-18. august 1994, Red Kåre Tønneson, Oslo 1994, s 16-32.

Arnórdóttir, Agnes S, Konur og vígamenn. Staða kynjanna á Íslandi á 12. og 13. öld, Reykjavík 1995.

Biskupa sögur I, (Bisk) Hi> íslenska bókmenntafélag, Kaupmannahöfn 1858, s 282.

Byock, Jesse, Medieval Iceland.. Society, Sagas and Power, Berkely/Los Angeles/London, 1988.

Byskupa sògur, (2. hafte), Biskop fiorlákr fiórhallssons levned og mirakler, (Bysk) utg Jón Helgason, København 1978.

Clunies Ross, Margaret, "Concubinage in Anglo-Saxon England”, Past \& Present, aug 1985, s 6 .

Diplomatorium Islandicum (DI), Band I, 834-1264, Hi íslenska bókmenntafélag, Kaupmannahöfn, 1857-76.

Goody, Jack The Development of Family and Marriage in Europe, Cambridge 1983.

Goody, Jack, Production and Reproduction. A Comparative Study of the Domestic Domain Cambridge

Jochens, Jenny; "The Church and Sexuality in Medieval Iceland", Journal of Medieval History 6, 1980; 
Jochens, Jenny; "The Politics of Reproduction: Medieval Norwegian Kingship", The American Historical Review, 1982:2;

Jochens, Jenny; "En Islande Médiévale: A la recherche de la famille Nucléaire", Annales, 1985a. Jochens, Jenny, "The Impact of Christianity on Sexuality and Marriage in the King' Sagas", The Sixth International Saga Conference 28/7-2/, 1985, Workshop Papers I, København 1985b. Jochens, Jenny; "Consent in Marriage: Old Norse Law, Life and Literature" Scandinavian Studies 58, 1986;

Jochens, Jenny; "The Politics of Reproduction, Medieval Norvegian Kingship", The American Historical Review, 92, 1987, s 327-349.

Jochens, Jenny; "The Illicit Love Visit: An Archaeology of Old Norse Sexuality", Journal of the History of Sexuality, vol 1:3 1991.

Jochens, Jenny, Women in Old Norse Society, Ithaca/London, 1995.

Magnúsdóttir, Auður, "Hövdingar, hustrur och frillor. Frilloväsendet på Island under fristatstiden", i Kirkehistorier. Rapport fra et middeladlersymposium, red Nanna Damsholt, Grethe Jacobsen, Niels Henrik Holmqvist-Larsen, København 1996. Nicholls, Kenneth Gaelic and Gaelicised Ireland in the Middle Ages, Dublin 1972.

Nors, Thyra, "Kampen om ægteskapet. En konfliktfyldt historie om kirkens førsøg på att genne lægfolk ind i den hellige ægtestand", Den Jyske historiker, 42, 1987.

Sigurðsson, Jón Viðar, Goder och maktforhold på Island $i$ fristatstiden, Bergen 1993.

Stafford, Pauline, Queens, Cuncubines and Dowagers. The King's Wife in the Early Middle Ages, London 1983.

Sturlunga saga, I-II, ed Jón Jóhannesson, Magnús Finnbogason og Kristján Eldjárn, Reykjavík 1946.

Wemple, Susan Women in the Frankish Society. Marriage and the Cloister 500-900, Philadelphia 1981.

\section{SUMMARY}

It is commonly accepted that marriage was an important political institution in the middle ages. Marriage was one way of making allies, confirming friendship between the two involved families, or even reconciliation. This was by no means different in the Icelandic freestate. Through marriage chieftains like Snorri Sturluson, and his brother fordur, both secured and increased their influence. On the other hand, both Snorri and fórdur had concubines; Snorri most likely while he still was married but fórdur between his two marriages. In fact, concubinage was common in the Icelandic freestate and the attempts of the church to abolish the custom had little effect.

Even though there were differences between legitimate marriage and concubinage my thesis is that both institutions were of great importance politically, perhaps even increasing in the struggle for power we witness in the last hundred years of the Icelandic freestate. The concubines were generally of lower social status than the men they had relations with, but frequently daughters of wealthy farmers with influence in their own territories. Becoming a concubine was probably a result of negotiation between two families, as was the case with marriage, and through this connection the women's father or/and brothers and the chieftain became allies.

Auf ur Magnúsdóttir

Historisk Institut

Göteborg Universitet 